The Geographical Journal of Nepal

Vol. 11: 45-62, 2018

Central Department of Geography,

Tribhuvan University, Kathmandu, Nepal

\title{
Physico-chemical properties of soil in Jita and Taksar area of Lamjung district, Nepal
}

\author{
Jitan Dahal ${ }^{1}$, Chhabi Lal Chidi ${ }^{1,2^{*}}$; Umesh Kumar Mandal ${ }^{1,2}$; Jyoti \\ Karki $^{1}$; Narendra Raj Khanal, ${ }^{1,2}$; and Ram Hari Pantha ${ }^{3}$ \\ ${ }^{1}$ Central Department of Geography, Tribhuvan University, Kathmandu, Nepal; \\ ${ }^{2}$ Sino-Nepal Joint Research Centre for Geography, Central Department of Geography, \\ Tribhuvan University, Kathmandu, Nepal; ${ }^{3}$ Ministry of Population and Environment, \\ Singha Durbar, Kathmandu, Nepal \\ (*Corresponding Author: chidichhabilal@gmail.com)
}

Physicochemical property of top layer of soil is very important for plant growth having life supporting agriculture production, forestry and environmental sustainability. Soil texture and its chemical properties are determined by various factors inversely soil property determines productivity for them. This study was conducted in Jita and Taksar area of Lamjung district of Nepal. Soil samples were collected from the field. Coarse fragments, soil texture and $\mathrm{pH}$ were measured from soil samples. Properties of soil were analyzed by mechanical and chemical methods such as sieve, hydrometer and digital pH meter. Dominant soil textural class is loam followed by silt loam. Higher proportion of sand is found in higher elevation and steeper slope. Inverse relationship is found of silt. Dominant soil is found to be slightly to moderately acidic. Soil $\mathrm{pH}$ level decreases with increasing altitude and slope gradient. Cultivated land is less acidic than other land cover category. It is found that lower elevation and lower slope gradient have more proportion of coarse fragments. Chi-square test proves the significant difference of $\mathrm{pH}$, soil texture class, soil particle size and coarse fragment at different elevation, slope gradient and land use. However, variation of sand at different slope gradient and land use is not explained well.

Keywords: Coarse fragment; Loam; Soil acidity; Soil pH; Soil texture 


\section{Introduction}

Soil is an important life supporting natural resource for the growth of arable crops, grassland and trees which produce life supporting materials for humans (Corstanje et al., 2006; Dorji et al., 2014; Mzuku et al., 2005) such as food, fiber for cloth, timber for building materials and fuel (Wild, 1996). Soil properties determine the composition of plant community structure and regeneration of plants (Sigdel, 2015; Tiwari, 2015) resulting on the variation of crop productivity and vegetation growth. Therefore, clear and intimate knowledge of soil properties and their distribution are essential pre-requirement in developing national and local level land use plans for agriculture, forestry and other uses (Mandal, 2013). Soil properties are physical and chemical characteristics of soil. Physical properties are texture, structure, density, porosity, consistency, temperature, color, and resistivity. Chemical properties are various chemical components in soil such as pH, nitrogen, phosphorous, potassium, etc. (Sigdel, 2015; Wild, 1996). Soil texture affects on soil water retention, leaching, erosion, nutrient storage, dynamics of organic matter and carbon sequestration capability. Therefore, soil texture analysis is key component in determining soil quality for agriculture and forestry development (Kettler et al., 2001). Soil pH is the measurement of soil acidic or alkaline level. It is the most important chemical indicator of soil quality which expresses the activity of the hydrogen ions in the soil solution. It affects the availability of mineral nutrients to plants as well as many soil processes (FAO, 2006). Additionally, rock fragments influences the nutrient status, water movement. It also shows the stage of development of the soil (Chow et al., 2007). Soil properties depend on various environmental factors like slope, aspect, climate, landscape, microclimate, topography and vegetation (Chen, 1997; Tsui, 2004). Mountainous country like Nepal has a very crucial landform, soil and climatic resources because of the mountain specificities such as diversity, fragility, marginality and inaccessibility (Mandal, 2013). Complex topographical feature has resulted complex types of physiochemical properties of soil even short span of spatial distance. In the past rapid population growth in the hill and mountain of Nepal resulted extension of cultivated land even steeply sloping area. It caused land degradation and decreasing productivity (Ekholm, 1975). Last two decades heavy outmigration of hill farmers have resulted labor shortage for agriculture and their land management system (Chidi 2016). However, agriculture is still the predominant economic activity in Nepal and there is an increasing demand for information on soils as a means to produce food. Food deficit, declining productivity of land and environmental degradation are directly related with the soil properties (Joshy, 2015, Dawadi et al., 2015) in Nepal. So, this study aims to assess the distribution of basic physiochemical properties of soil such as texture and $\mathrm{pH}$ of soil including coarse fragments. 


\section{Study area}

The study area is selected from middle mountain region of Nepal having subtropical and warm temperate climatic region. The study area is Taksar and Jita area of Lamjung district of Madi river basin (Figure 1). This study is joining with Golandi Khola to the east, Kunchha area to the west, Deuralidanda area to the north and Ristikhola to the south. District road connects this area from the other parts of the country.

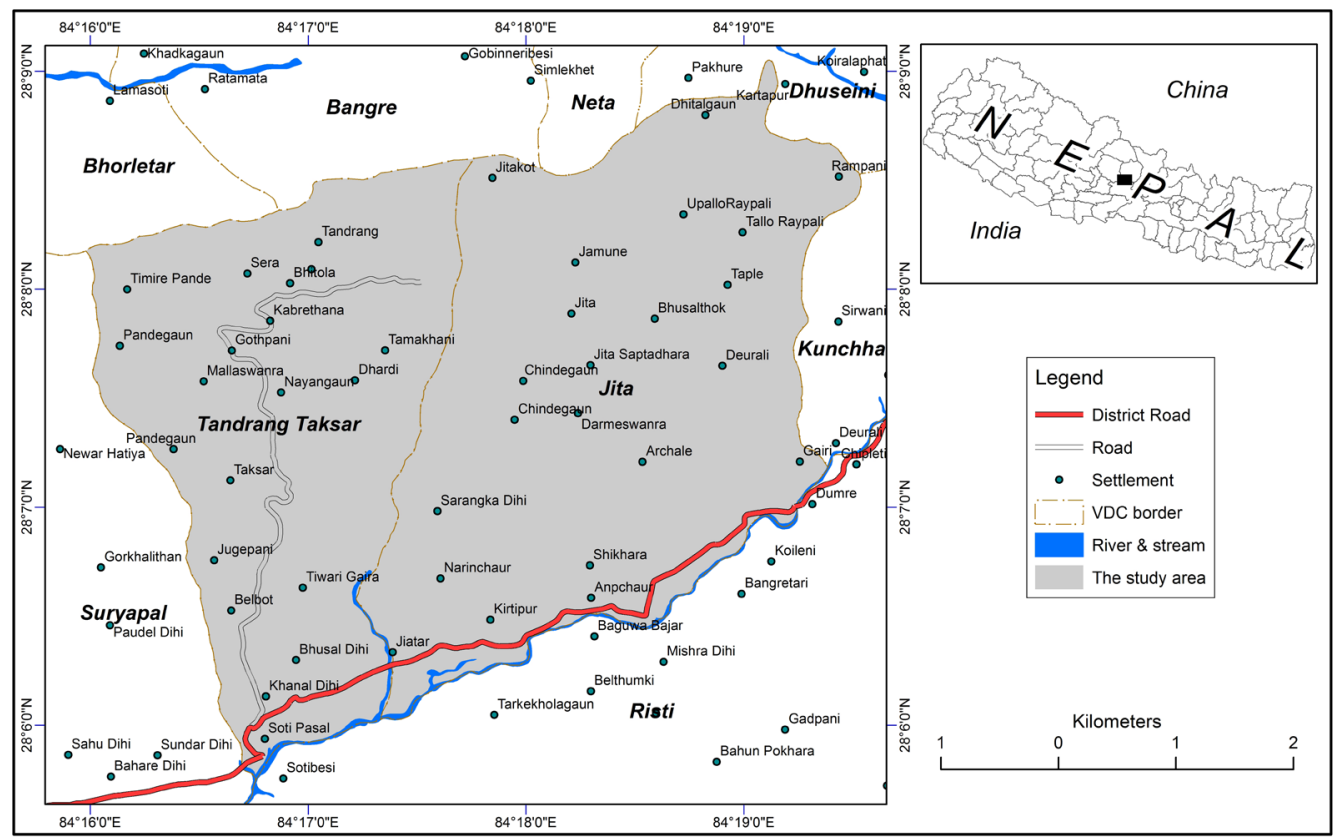

Figure 1: Study area :Taksar and Jita area.

The geographical extension of the study area is $84^{\circ} 15^{\prime} 59^{\prime \prime}$ east to $84^{\circ} 19^{\prime} 33^{\prime \prime}$ east longitude and $28^{\circ} 5^{\prime} 46^{\prime \prime}$ north to $28^{\circ} 9^{\prime} 30^{\prime \prime}$ north latitude. Aerial extension is nearly 21 square $\mathrm{km}$ having east-west extension nearly 6 kilometer and north south 5.5 kilometer. Elevation ranges from lowest $420 \mathrm{~m}$ in the south-west corner to highest $1420 \mathrm{~m}$ to the north. Naturally, general slope is south facing having higher elevation to the north and lower to the south. Temperature and rainfall data was taken from the nearest meteorological stations. Rainfall data was taken from nearest rainfall data of meteorological station at Kunchha is nearly $2600 \mathrm{~mm}$ having nearly $80 \%$ rainfall in summer and dry in winter. Kunchha is the nearest station but this station does not have temperature data. Therefore, temperature data was taken from second nearest station located at Khudi. Average temperature of Khudi is $22.5^{\circ} \mathrm{c}$ having the maximum $28.64^{\circ} \mathrm{c}$ and minimum is $16.39^{\circ} \mathrm{c}$. Narrow river terraces along the tributaries and gently sloping cultivated land 
and most of other parts are moderately to steeply sloping hillside. Traditional intensive subsistence farming with irrigated paddy field at lower river terraces and rain-fed maize field in the upper hill slope area is common in Nepal. It is primarily based on organic manure with livestock, forest and crop are being major components of an integrated system and this area is also not an exception.

\section{Methods and materials}

This study is based on the analysis of 50 samples taken from different areas. The location of sample pits were identified on the basis of various map layers such as topographic map, land system map, land capability map and land utilization map (LRMP, 1986a; LRMP, 1986b; LRMP, 1986c). The centroid method was applied to find the location for soil pits in the polygons. Coordinates of each sampled pits were identified. Standard soil profile description prepared by National Land Use Project, Nepal (NLUP, 2074) was used to record the soil profile details. This form consists of the information of sampled site location, general information of the soil, general information of the profile and information on individual soil horizon. One $\mathrm{kg}$ top soil from each pits were collected. The map of sampled pit location has been shown in the Figure 2. Google Earth image was also used to collect required information and verification of spatial data.

Samples were air dried in the room. Roots, stem leaves etc. were cleaned. Air dried sampled was grinded to disintegrate fragment of earth materials. Grinded sample was filtered by $2 \mathrm{~mm}$ sieve and weighted separately. Earth material greater than $2 \mathrm{~mm}$ is known as coarse fragments and smaller than $2 \mathrm{~mm}$ is known as soil (FAO, 2006). Soil particle size of $2 \mathrm{~mm}$ to $0.05 \mathrm{~mm}$ was defined as sand, $0.05 \mathrm{~mm}$ to $0.002 \mathrm{~mm}$ was silt and smaller than 0.002 $\mathrm{mm}$ is clay (USDA, 2017). It is measured by hydrometer which is recommended

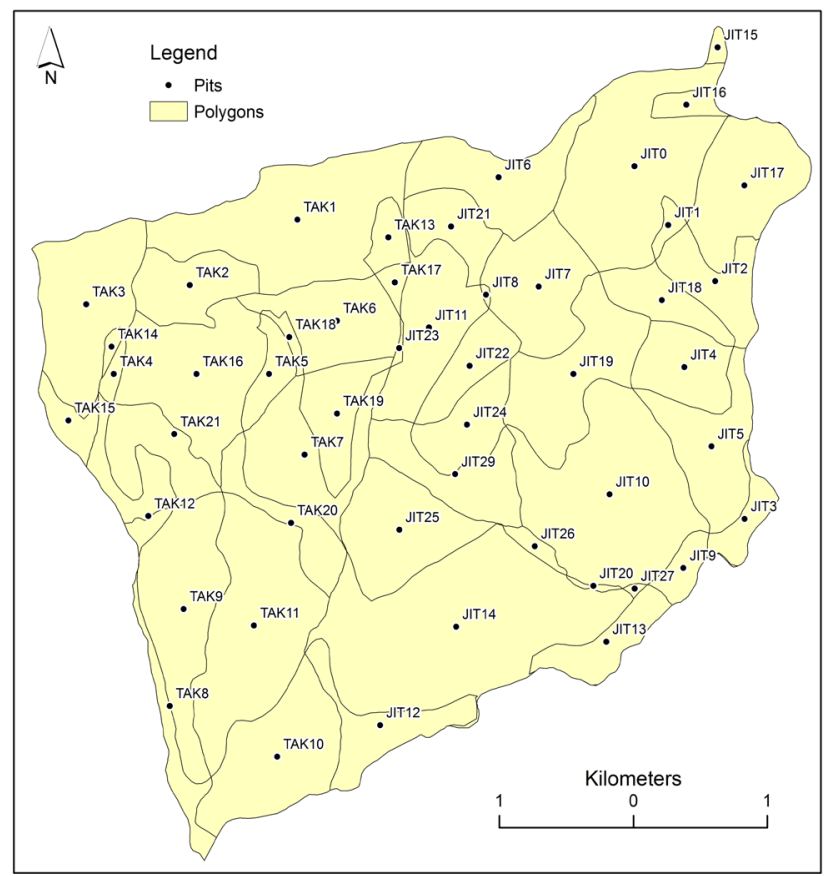

Figure 2: Soil mapping unit and location of sampled pits. 
standard method for particle size identification (Amuyou et al., 2013). Then proportion of sand, silt and clay of each soil sample was identified. Soil $\mathrm{pH}$ was measured using digital $\mathrm{pH}$ meter in the lab. Soil $\mathrm{pH}$ ranking was done on the basis of Nepal Agriculture Research Council guideline (NARC, 2013). Only four groups of $\mathrm{pH}$ ranking were found in the study area. Soil texture class was identified through soil texture triangle for each sample (see Figure 3).

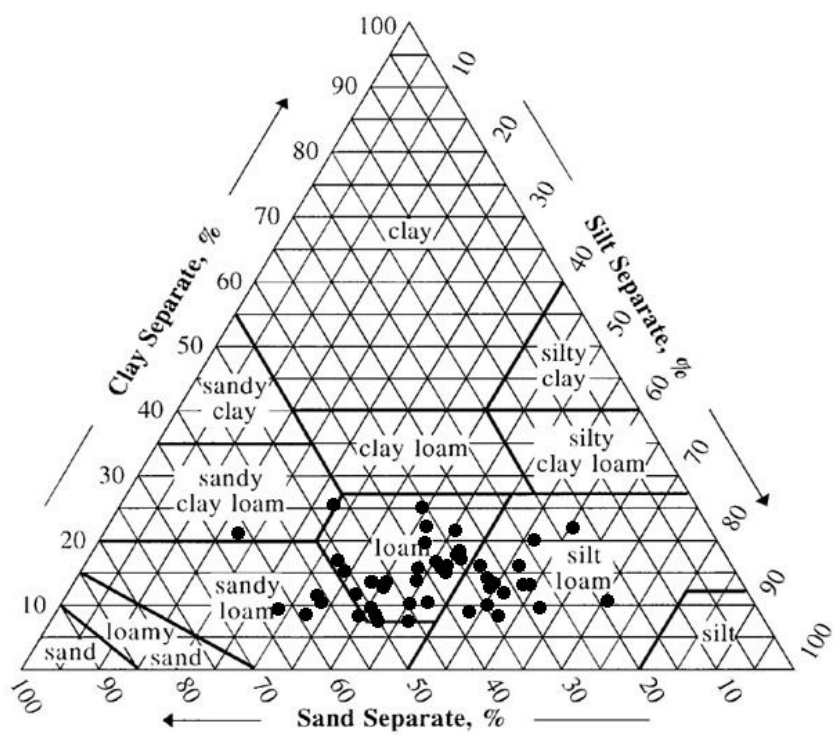

Figure 3: Soil texture triangle.

Land use map was prepared on the basis of topographic map 1996 and corrected by field verifications and Google Earth image. Land use classes were agriculture, forest and others (pasture and grassland).

IDW interpolation of soil properties in GIS is popular methods (Mzuku et al., 2005 and Attaeian et al., 2015) to make regular pattern on the basis of the properties of sample location which is the best method due to the low skewness inherent in all soil properties (Kravchenko and Bullock, 1999). This method was used cautiously in this study because some studies found that IDW was the best for subsoil $\mathrm{pH}$ interpolation than top soil (Robinson and Metternicht, 2006). Elevation of 200 meter interval was considered. Slope has been classified into four categories such as $<1^{\circ}, 1^{\circ}$ to $5^{\circ}, 5^{\circ}$ to $30^{\circ}$ and $>30^{\circ}$ according slope category of land capability classes I, II III and IV (LRMP, 1986a). Cross tables of corresponding variables were developed to identify the pattern of association among variables. 
Two types of soil properties tables were prepared at different elevation, slope gradient and land use. First one was for contingency tables of soil properties at different elevation, slope gradient and land use to identify the nature of distribution pattern of soil properties. Second one was to prepare frequency table of soil properties of 50 samples for Chi-square test to identify whether the general distribution pattern of soil properties at different elevation, slope gradient and land use are significantly different or not. For this purpose, variables were further grouped to meet the criteria for chi-square test (Pal, 1982 and Gupta, 2011). Elevation was classified into tropical below 1000 meter and warm temperate regions above 1000 meter according to LRMP criteria. Similarly, slope was grouped into $0^{\circ}$ to $5^{\circ}$ and $5^{\circ}$ to $60^{\circ}$. First group is class I and class II, and the second group is class III and class IV of land capability class (LRMP, 1986a). First group of soil texture class was loamy (loam and silt loam) and second group was sandy (sandy clay loam and sandy loam) because these classes have different water retention and moisture holding capacity (Akhter, 2004). Soil was classified into two groups on the basis of alkaline and acidic in nature which is very important for crop production and vegetation regeneration (Nelson and $\mathrm{Su}, 2010$ ). First group is neutral to slightly acidic and second one is moderately to highly acidic. Sand percent is grouped into sandy nature ( $>50 \%$ sand) and silt or clay nature $(<50 \%$ sand). Accordingly, silt percent was grouped into clay nature ( $<40 \%$ silt) and silt nature ( $>40 \%$ silt). Clay was grouped into less than $20 \%$ and more than $20 \%$ (NARC, 2013). Coarse fragment proportion was grouped into boulder (less than 15\% coarse fragment) and rubble (more than 15\% coarse fragment) based on USDA (2017) class. Finally, chi-square test was used to test whether the significance association among variables presents.

\section{Results and discussion}

\section{Soil texture}

Soil texture refers to the relative proportion of sand, silt and clay of soil. Four types of texture classes were identified from 50 soil samples. Those are loam, silt loam, sandy loam and sandy clay loam. Dominant soil texture class in the study area is loam (54.03\%) followed by silt loam $35.94 \%)$. These two texture classes occupy nearly $90 \%$ of the soil. Remaining 10 percent are sandy loam (7\%) and sandy clay loam (3\%). There is higher proportion of loam and silt loam below 1000 meter elevation inversely higher proportion of sandy loam and sandy clay loam above 1000 meter altitude. Chi-square test (Table 1) between elevation and soil texture class proves the association between these two variables. Similar association with slope gradient and land use was found by chi-square test at $5 \%$ significance level. Therefore, it can be said that elevation and slope gradient have significant control on the distribution of soil texture class. Distribution of 
soil texture class was also determined by various land use classes such as agriculture, forest and others (pasture and grassland). Cultivated land has higher proportion of loam and silt loam than forest and other land uses (at 5\% significance level). Inversely, pasture and grassland have more sandy loam and sandy clay loam. Irrigated paddy field has more silt loam and rain fed maize field has more loamy soil. Silt loam is mostly limited to river terraces and tars. The lower river terrace with paddy field has silt loam and upper river terrace of maize field has mostly loamy soil.

Table 1: Chi-square results of soil texture class at different elevation, slope gradient and land use $(\mathrm{N}=50)$.

\begin{tabular}{|l|r|r|}
\hline Variables & Chi square value & \multicolumn{2}{c|}{$\mathrm{p}$ value } \\
\hline Elevation & 0.03 & 0.854 \\
\hline Slope & 2.09 & 0.148 \\
\hline Land use & 5.55 & 0.062 \\
\hline
\end{tabular}

Soil texture class provides valuable information for many applications in soil science and other disciplines. However, values of sand, silt, and clay of soil are preferable due to limitations of soil texture class (Levi, 2017). Sand proportion is increasing with increasing elevation and naturally silt proportion is opposite to elevation. Clay proportion is also similar decreasing trend with increasing elevation (see Table 2).

Table 2: Average percentage of sand, silt and clay by elevation

\begin{tabular}{|l|r|r|r|r|}
\hline Elevation in meter & \multicolumn{1}{|c|}{ Number of samples } & \multicolumn{1}{|c|}{ Sand } & \multicolumn{1}{c|}{ Silt } & \multicolumn{1}{c|}{ Clay } \\
\hline 400 to 600 & 14 & 35.0 & 50.9 & 14.1 \\
\hline 600 to 800 & 10 & 43.0 & 43.4 & 13.6 \\
\hline 800 to 1000 & 16 & 44.7 & 41.7 & 13.6 \\
\hline 1000 to 1250 & 10 & 46.8 & 40.7 & 12.5 \\
\hline Total & 50 & 42.1 & 44.4 & 13.5 \\
\hline
\end{tabular}

Chi-square test (at 5\% significance level) of elevation and sand proportion proved the significant variation of sand above and below 1000 meter altitude. Similar result was found in Laddakh, India (Charan et al., 2013) at 3000 meter to 4000 meter altitudinal range. Silt and clay proportion decreases with increasing altitude (see Table 2). However, chi-square test at $5 \%$ significant level does not show the significant association. Slope is another important factor determining the proportion of sand, silt and clay. Table 3 shows the increasing proportion of sand with increasing slope gradient and inverse relation of 
silt and clay context. The lowest slope gradient is nearby river channel therefore it has higher sand proportion and lower proportion of silt and clay in comparison to $1^{\circ}$ to $5^{\circ}$ slope range. It proves that land capability Class I and Class II have lower proportion of sand and higher proportion of silt and clay than in Class III and Class IV. However, Chisquare test does not prove the significant difference in the proporation of sand and silt at less than and more than $5^{\circ}$ slope gradient but clay proporation is significantly different in these two slope gradient classes..

Table 3: Average percentage of sand, silt and clay by slope gradient

\begin{tabular}{|l|r|r|r|r|}
\hline Slope in degree & \multicolumn{1}{|c|}{ Number of samples } & \multicolumn{1}{|c|}{ Sand } & \multicolumn{1}{c|}{ Silt } & \multicolumn{1}{c|}{ Clay } \\
\hline 0 to 1 & 2 & 31.1 & 54.3 & 14.6 \\
\hline 1 to 5 & 6 & 28.9 & 55.8 & 15.3 \\
\hline 5 to 30 & 26 & 42.6 & 44.3 & 13.1 \\
\hline More than 30 & 16 & 47.6 & 39.0 & 13.4 \\
\hline Total & 50 & 42.1 & 44.4 & 13.5 \\
\hline
\end{tabular}

Proportion of sand is the lowest in agriculture and the highest is in pasture and grassland. Proportion of silt is the highest (47.3\%) in agriculture land followed by grassland $(45.9 \%)$ and the least is in forest. Clay percent is the highest in agriculture and the least proportion is in the forest (see Table 4). Silt and clay proportion are significantly different in various land use but sand proportion is not as well (chi-square test at 5\% significance level).

Table 4: Average percentage of sand, silt and clay by land use

\begin{tabular}{|l|r|r|r|r|}
\hline Land use & \multicolumn{1}{|c|}{ Number of samples } & \multicolumn{1}{c|}{ Sand } & \multicolumn{1}{c|}{ Silt } & \multicolumn{1}{c|}{ Clay } \\
\hline Agriculture & 31 & 38.6 & 47.3 & 14.1 \\
\hline Forest & 13 & 48.5 & 39.2 & 12.3 \\
\hline Grassland \& pasture & 6 & 45.9 & 40.6 & 13.6 \\
\hline Total & 50 & 42.1 & 44.4 & 13.5 \\
\hline
\end{tabular}

Table 2, 3 and 4 show that higher proportion of sand was found at higher elevation, higher slope gradient and non agriculture land. It is also because of the cultivated land is mostly locating in lower elevation less sloppy land. Higher proportion silt and clay at lower elevation, lower slope gradient and cultivated land indicates the land suitability for agriculture. 


\section{Soil pH}

The presence of bacteria, decomposing materials like leaves, grasses and addition of lime has direct relation in maintaining the soil $\mathrm{pH}$. Since soil $\mathrm{pH}$ is controlled by several factors such as clay and organic matter content. IDW Interpolated map of $\mathrm{pH}$ estimates that more than half of the total area is moderately acidic followed by slightly acidic. Remaining area is strongly acidic. Very few parts are neutral. Figure 4 shows the distribution of moderate to highly acidic soil in the north and western part of the study area which is mostly surrounded by moderately acidic. Slightly acidic soil is found in the central to south east portion. Some eastern, southern, western and northern border area have also similar level of $\mathrm{pH}$. Neutral is in the very limited part of central, west and southeast region.

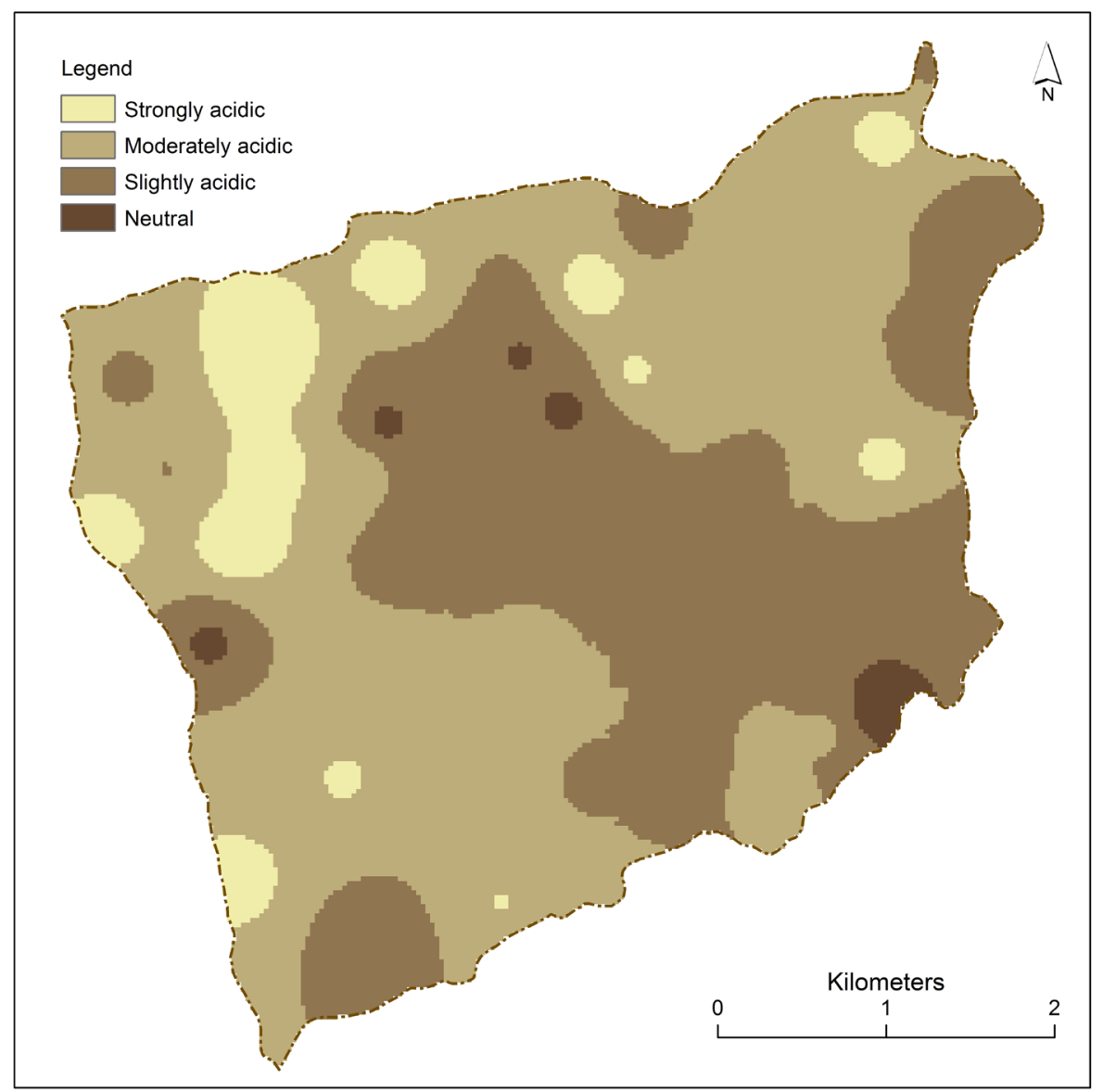

Figure 4: Distribution of alkaline and acidic nature of soil 
Table 5 shows the number of soil samples taken from different types of land use and their $\mathrm{pH}$ values.

Table 5: Soil $\mathrm{pH}$ by land use types

\begin{tabular}{|l|r|r|r|r|}
\hline \multirow{2}{*}{ Land use } & \multirow{2}{*}{ Number of samples } & \multicolumn{3}{|c|}{ Soil $\mathrm{pH}$} \\
\cline { 3 - 5 } & & Minimum & Maximum & Average \\
\hline Agriculture & 31 & 5.3 & 7.0 & 6.0 \\
\hline Forest & 13 & 5.3 & 6.4 & 5.8 \\
\hline Pasture and grassland & 6 & 5.1 & 6.6 & 5.8 \\
\hline Total & 50 & 5.1 & 7.0 & 5.9 \\
\hline
\end{tabular}

Inverse relation between slope gradient and average $\mathrm{pH}$ value is found in the study area (see Table 6). Maximum $\mathrm{pH}$ is found in $1^{\circ}$ to $5^{\circ}$ slope range. Amuyou and others (2013) and Tripathi (2015) found the significant increase in soil acidity in Nepal and other parts of the world and this study also found similar result.

Table 6: Soil pH by slope gradient

\begin{tabular}{|l|r|r|r|r|}
\hline \multirow{2}{*}{ Land use } & \multirow{2}{*}{ Number of samples } & \multicolumn{3}{|c|}{ Soil $\mathrm{pH}$} \\
\cline { 3 - 5 } & & \multicolumn{1}{|c|}{ Minimum } & Maximum & \multicolumn{1}{c|}{ Average } \\
\hline 0 to 1 & 2 & 6.1 & 6.4 & 6.3 \\
\hline 1 to 5 & 6 & 5.6 & 7.0 & 6.2 \\
\hline 5 to 30 & 26 & 5.1 & 6.7 & 6.0 \\
\hline 30 to 60 & 16 & 5.3 & 6.6 & 5.7 \\
\hline Total & 50 & 5.1 & 7.0 & 5.9 \\
\hline
\end{tabular}

However, soil $\mathrm{pH}$ pattern is not regular with altitudinal variation in the study area. Agriculture land is more alkaline than forest, grassland and pasture area. Irrigated paddy field has higher $\mathrm{pH}$ value than in rain fed maize field. However, average soil $\mathrm{pH}$ at agriculture land is slightly acidic.

There has been variation in soil acidity above and below 1000 meter elevation and different land use types. The significant difference of soil acidity and alkaline below and above $5^{\circ}$ slope gradient was found in the study area. Chi-square test proves the significant difference of soil $\mathrm{pH}$ class in various land use class at $5 \%$ significance level (Table 7). It proves that the soil $\mathrm{pH}$ is significantly higher in agriculture land than forest, pasture and grassland. 
Table 7: Chi square result of soil $\mathrm{pH}$ at different elevation, slope gradient and land use $(\mathrm{N}=50)$.

\begin{tabular}{|l|r|r|}
\hline Variables & Chi square value & \multicolumn{2}{|c|}{ p value } \\
\hline Elevation & 2.42 & 0.119 \\
\hline Slope & 0.42 & 0.517 \\
\hline Land use & 2.86 & 0.239 \\
\hline
\end{tabular}

Acidic soil in agriculture land is the result of shortage of organic manure supply due to the decreasing livestock and other organic manure supply due to labor shortage in hill agriculture (Tripathi and Jones, 2010) of Nepal. Hill farming system of Nepal is characterized by the integration of crop production, livestock and forestry. In recent two decades linkage between these aspects are becoming weak. As a result organic manure supply in their cropping field is lacking which is being major cause decreasing soil productivity (Dawadi and Thapa, 2015). Similarly, soil erosion from the hill slope and weak management system of agriculture farmland (Tripathi, 2015) have also played significant role of decreasing soil productivity and acidification of agriculture land. Soil becomes acidic through natural process after expose with rainwater for a long time. Acidification of soil is a major problems of agriculture sustainability in the world (Sumner and Noble, 2003; Brady and Weil, 2008). The similar situation is also found in Nepal.

\section{Coarse fragments}

Coarse fragments play an important role in static soil properties such as soil bulk density, porosity, pore size distribution and saturated hydraulic conductivity. In general, these values increased with increasing coarse fragment content (Chow et al., 2007). Soil moisture and temperature of soil are also determined by the proportion of coarse fragments which is both valuable components for agriculture production. There is higher proportion of coarse fragment in the river terraces followed by slope land. Average coarse fragment proportion in the study area is 18.69 percent with ranging minimum nearly $2 \%$ to as high more than $90 \%$.

Coarse fragment is highest in agriculture land followed by pasture and grassland. Least proportion is in the forest area (see Figure 5). Land use has significant difference of the distribution of boulder and rubble (chi square test at 5\% significance level) in the study area. 


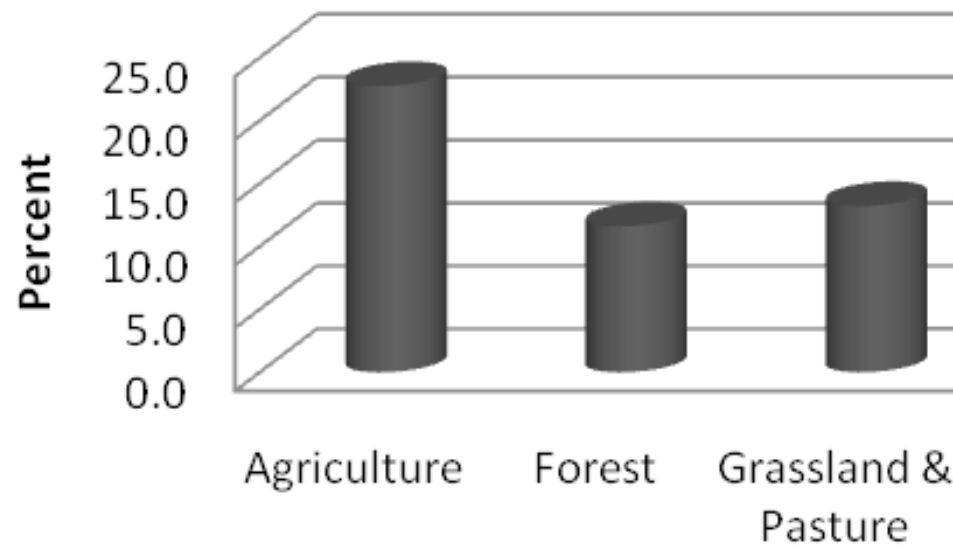

Figure 5: Average percent of coarse fragment by land use.

The proportion of coarse fragment is consistently decreasing with increasing altitude (Table 8). The maximum proportion is in similar pattern like average but minimum proportion is not consistent with elevation. The distribution of boulder and rubble is significantly different below and above 1000 meter elevation (chi-square test at 5\% significance level).

Table 8: Coarse fragment by elevation.

\begin{tabular}{|l|r|r|r|r|}
\hline Altitude in meter & Numbers of sample & Minimum & Maximum & \multicolumn{1}{c|}{ Average } \\
\hline 400 to 600 & 14 & 3.3 & 90.4 & 35.6 \\
\hline 600 to 800 & 10 & 1.9 & 44.6 & 14.4 \\
\hline 800 to 1000 & 16 & 3.2 & 26.8 & 12.7 \\
\hline 1000 to 1250 & 10 & 2.5 & 29.5 & 8.8 \\
\hline Total & 50 & 1.9 & 90.4 & 18.7 \\
\hline
\end{tabular}

The proportion of coarse fragment increases with decreasing slope gradient. However, lower proportion of coarse fragment was found below $1^{\circ}$ than higher slope gradient class $1^{\circ}$ to $5^{\circ}$ class. Slope gradient class $1^{\circ}$ to $5^{\circ}$ has the highest proportion of coarse fragment (see Table 9). The distribution of these two types of class is significantly different in the regions more than and less than $5^{\circ}$ slope gradient. Chi-square test proves that there is significantly higher proportion of coarse fragment less than $5^{\circ}$ slope gradient than steeper slope. 
Table 9: Coarse fragments by slope gradient.

\begin{tabular}{|l|r|r|r|r|}
\hline Land use & \multicolumn{1}{|c|}{ Number of samples } & \multicolumn{1}{c|}{ Minimum } & \multicolumn{1}{c|}{ Maximum } & \multicolumn{1}{c|}{ Average } \\
\hline 0 to 1 & 2 & 6.0 & 76.7 & 41.3 \\
\hline 1 to 5 & 6 & 9.3 & 90.4 & 53.1 \\
\hline 5 to 30 & 26 & 1.9 & 44.6 & 14.4 \\
\hline 30 to 60 & 16 & 2.9 & 29.3 & 10.0 \\
\hline Total & 50 & 1.9 & 90.4 & 18.7 \\
\hline
\end{tabular}

Mass-volume relationships are crucial in estimating soil fertility. The amount of gravel present in soil affects bulk density and availability of nutrients. Hence, void space occupied by gravel can hardly be ignored. The quantity of soil organic carbon and potentially available nutrients for plant uptake decreases with an increase in volume of coarse fragments (Nagaraja et al., 2016 and Poeplau, 2017). There is higher proportion of coarse fragment at lower elevation, lower slope gradient and cultivated land. These areas are less suitable for agriculture in case of the presence of higher proportion of coarse fragment. However, other suitable environment such as soil $\mathrm{pH}$, soil texture class, topography, slope gradient and climate have made possible for cultivation.

\section{Conclusion}

Physicochemical properties of soil are the important components. Detail spatial information of soil properties is very essential for having sustainable agriculture and environmental management. Dominant soil texture class in the study area was found loam followed by silt loam. Remaining are sandy loam and sandy clay loam. Proportion of sand increases with increasing altitude and slope gradient and silt proportion is quite inverse which is similar to some other parts of the world. Higher proportion of sand is in steeper slope, rain fed maize field and lower proportion in agriculture land. It is natural because steeper surface faces more sheet erosion of finer material during summer rainfall. Frequent tilling of cultivated land result more contain of silt than other land cover categories. Most of the study area is slightly to moderately acidic which occupies nearly $91 \%$ of total area and very few area has neutral. Northern and western parts are more acidic than central and southeastern portion. Acidity increases with increasing altitude and slope steepness as a result irrigated paddy field have more $\mathrm{pH}$ than in rain fed maize field. Acidification of soil of cultivated land is resulted due to the lack of organic manure supply and because of the soil erosion due to lack of proper 
management of cultivated land. Higher proportion of coarse fragment at lower elevation and lower slope gradient because of the weathered materials are deposited at lower slope gradient of lower altitude area because lowlands are more flat than the land of higher elevation. This study is limited in two sites of Lamjung district and difficult to generalize soil characteristics at larger scale. Exploring more soil characteristics with such detail spatial coverage of different parts is recommended for the future research in the field of soil science.

\section{Acknowledgements}

The present paper is based on the study supported by the project "Ecosystem-based Adaptation through South-South Cooperation (EbA South)", which is a full-sized GEF project, funded through the Special Climate Change Fund. Officially known under the title "Enhancing Capacity, Knowledge and Technology Support to Build Climate Resilience of Vulnerable Developing Countries", the project is implemented by United Nations Environment Programme and executed by the National Development and Reform Commission of China through the Institute of Geographic Sciences and Natural Resources Research, Chinese Academy of Sciences.

The test of soil samples was carried out in the soil laboratory of Sino-Nepal Joint Research Centre for Geography within the Central Department of Geography which was established with the help of Institute of Mountain Hazards and Environment (IMHE), Chinese Academy of Sciences (CAS), Chengdu and financial support from the Ministry of Science and Technology, China. The authors would like to thank the EbA South project for its support to the fieldwork and Sino-Nepal Joint Research Centre for Geography for laboratory facilities.

The authors would also like to thank Dr. Anthony Mills, Dr. Pierree Begat and Dr. Robert Raw from C4 EcoSolutions, Prof. Deng Wei and Prof. Xiong Donghong from IMHE and two unanimous reviewers for their help in improving the manuscript by providing comments and suggestions.

\section{Reference}

Akhter, J., Mahmood, K., Malik K. A., Mardan A., Ahmad M., \& Iqbal, M. M. (2004). Effects of hydrogel amendment on water storage of sandy loam and loam soils and seedling growth of barley, wheat and chickpea. Plant Soil Environment, 50 (10): 463-469. 
Amuyou, U. A., Eze, E. B., Essoka, P. A., Efiong, J., \& Egbai, O. O. (2013). Spatial variability of soil properties in the Obudu Mountain Region of Southeastern Nigeria. International Journal of Humanities and Social Science, 3(15): 145149.

Attaeian, B., Farokhzadeh, B., Akhzari, D., Artimani, M. M., \& Souri, M. (2015). Comparing interpolation methods for estimating spatial distribution of topsoil $\mathrm{pH}$ and EC (Case Study: Karimabad Rangelands, Hamadan Province, Iran). ECOPERSIA, 3(4): 1145-1159.

Brady, N. C., \& Weil, R. R. (2008). The Nature and Properties of Soils, 14th ed. Upper Saddle River, NJ: Pearson Education.

Charan, G., Bharti, V. K., Jadhav, S.E, Kumar, S., Acharya, S., Kumar, P., Gogoi, D., \& Srivastava, R.B. (2013). Altitudinal variations in soil physico-chemical properties at cold desert high altitude. Journal of Soil Science and Plant Nutrition, 13 (2): 267-277.

Chen, Z. S., Hsieh, C. F., Jiang, F. Y., Hsieh, T. H., \& Sun, I. F. (1997). Relationships of soil properties to topography and vegetation in a subtropical rain forest in southern Taiwan. Plant Ecology, 132: 229-241.

Chidi, C. L. (2016). Determinants of cultivated land abandonment in the hills of western Nepal. Studia Ubb Geographia, 61(1): $101-116$.

Chow, T. L., Rees, H. W., Monteith, J. O., Toner, P., \& Lavoie, J. (2007). Effects of coarse fragment content on soil physical properties, soil erosion and potato production. Canadian Journal of Soil Science, 87: 565-577.

Corstanje, R., Grunwald, S., Reddy, K. R., Osborne, T. Z., \& Newman, S. (2006). Assessment of the spatial distribution of soil properties in a Northern Everglades marsh. Journal of Environmental Quality, 35:938-949.

Dawadi, D. P. \& Thapa, M. (2015). Soil fertility status of Nepal: Report from laboratory analysis of soil samples of five development regions. Proceedings of the Second National Soil Fertility Research Workshop, 42-52. Lalitpur: National Agriculture Research Council (NARC).

Dawadi, D. P., Risal, C. P., Maskey, K. H., Rijal, B. \& Thapa, T. B. (2015). Mobile soil testing laboratory (MSTL): Experiences of soil management directorate to aware farmers about soil health. Proceedings of the Second National Soil Fertility Research Workshop, 6-15. Lalitpur: National Agriculture Research Council (NARC). 
Dorji, T, Inakwu, O. A. O., \& Field, D. J. (2014). Vertical distribution of soil organic carbon density in relation to land use/cover, altitude and slope aspect in the Eastern Himalayas. Land, 3: 1232-1250.

Ekholm, E. (1975). The deterioration of mountain environments, Science, 189: 764 770 .

FAO (2006). Guidelines for Soil Description (Fourth edition). Rome: Food and Agriculture Organization of the United Nations.

Gupta, S. C. (2011). Fundamentals of Statistics. (6 $6^{\text {th }}$ Edition). Mumbai: Himalaya Publishing House Pvt. Ltd.

Joshy, D. (2015), Soils and food production. Proceedings of the Second National Soil Fertility Research Workshop, 1-5. Lalitpur: National Agriculture Research Council (NARC).

Kettler, T. A., Doran, John W., \& Gilbert, T. L. (2001). Simplified method for soil particle-size determination to accompany soil-quality. Soil Science Society of American Journal, 65:849-852.

Kravchenko, A. N., \& Bullock, D. G. (1999). A comparative study of interpolation methods for mapping soil properties. Journal of Agronomy, 91: 393-400.

Levi, M. R. (2017). Modified centroid for estimating sand, silt, and clay from soil texture class. Soil Science Society of America Journal, 81:578-588.

LRMP, (1986a). Land Capability Report. Ottawa: Land Resource Mapping Project, Kenting Earth Sciences Limited.

LRMP, (1986b). Land System Report. Ottawa: Land Resource Mapping Project, Kenting Earth Sciences Limited.

LRMP, (1986c). Land Use Report. Ottawa: Land Resource Mapping Project, Kenting Earth Sciences Limited.

Mandal, U. K. (2013). Land Suitability analysis for sustainable landuse planning in Maheshkhola Watershed, Central Mountain Region, Nepal. In: B. P. Subedi and P. C. Poudel (Eds.), The Himalayan Review, 64: 71-85. Kathmandu: Nepal Geographical Society.

Mzuku, M., Khosla, R., Reich, R., Inman, D., Smith, F., \& MacDonald, L. (2005). Spatial variability of measured soil properties across site-specific management zones. Soil Science Society of America Journal, 69:1572-1579.

Nagaraja, M. S., Bhardwaj, A. K., Reddy, G. V. P., Srinivasamurthy, C. A., \& Kumar, S. (2016). Estimations of soil fertility in physically degraded agricultural soils |60|| 
through selective accounting of fine earth and gravel fractions. Solid Earth, 7: 897-903. doi:10.5194/se-7-897-2016

Nelson, P. N., \& Su, N. (2010). Soil pH buffering capacity: a descriptive function and its application to some acidic tropical soils. Australian Journal of Soil Research, 48: 201-207.

NLUP (2074). National Land Use Project. Kathmandu: National Land Use Project, Middle Baneshwor, Kathmandu.

NARC (2013). Methods of Soil Sample Collection and Analysis. Soil Science Division, Council of National Agriculture Research, National Agriculture Research Center, Khumaltar, Lalitpur, Nepal.

Pal, S. K. (1982). Statistical Methods: A Basic Approach to Geography. New Delhi: Tata McGraw-Hill Publishing Company Limited.

Poeplau, C., Vos, C., \& Don, A (2017). Soil organic carbon stocks are systematically overestimated by misuse of the parameters bulk density and rock fragment content. SOIL, 3, 61-66. doi:10.5194/soil-3-61-2017.

Robinson, T. P., \& Metternicht, G. (2006). Testing the performance of spatial interpolation techniques for mapping soil properties. Computers and Electronics in Agriculture, 50: 97-108.

Sigdel, S. R., Rupakheti D., Baral U., Tripathee L., Aryal, R., Dhital, S. \& Sharma P. (2015). Physico-chemical characteristics of soil along an altitudinal gradients at southern aspect of Shivapuri Nagarjun National Park, Central Nepal. International Research Journal of Earth Sciences, 3(2): 1-6.

Sumner, M. E., \& Noble, A. D. (2003). Soil acidification: The world story. In: Z . Rengel (Ed), Handbook of Soil Acidity, 1-28. New York: Marcel Dekker.

Tiwari, K. R. (2015). Soil types and fertility status in Western Tarai Region of Nepal: A case study of Bankatawa VDC of Banke district. Proceedings of the Second National Soil Fertility Research Workshop, 308-314. Lalitpur: National Agriculture Research Council (NARC).

Tripathi, B. P., \& Jones, J. E. (2010). Biophysical and socio-economic tools for assessing soil fertility: A case of western hills, Nepal. Agronomy Journal of Nepal, 1: $1-9$.

Tripathi, B. P. (2015). Soil degradation and its management, Proceedings of the Second National Soil Fertility Research Workshop, 26-35. Lalitpur: National Agriculture Research Council (NARC). 
J. Dahal, C.L. Chidi,U. K. Mandal ... / The Geographical Journal of Nepal Vol. 11: 45-62, 2018

Tsui C. C., Chen Z. S., \& Hsieh C. F. (2004). Relationships between soil properties and slope position in a lowland rain forest of southern Taiwan. Geoderma, 123: $131-142$.

USDA (2017). Soil Survey Manual. United States Department of Agriculture.

Wild, A. (1996). Soil and the Environment: An Introduction. Cambridge: Cambridge University Press. 